\title{
Internal Control, Cross-border Mergers, Cultural Integration and Merger Performance
}

\author{
Xin $\mathrm{Jin}^{1, \mathrm{a}}$ and Bailing $\mathrm{Hu}^{2, \mathrm{~b}}$ \\ ${ }^{1}$ Zhenjiang College, Zhenjiang, Jiangsu, China \\ ${ }^{2}$ Jiangsu University, Zhenjiang, Jiangsu, China \\ a535795453@qq.com, b574911482@qq.com
}

Keywords: Internal Control; Cross-border Mergers; Cultural Integration; Performance

\begin{abstract}
Select the 2015-2016 takeover of listed companies have already completed the merger of enterprises in transnational mergers and acquisitions as the sample, the system of internal control quality on the influence of culture integration in transnational merger and acquisition ability and performance of cross-border mergers and acquisitions, the empirical analysis shows that the higher the quality of internal control, enterprise transnational merger and acquisition of cultural integration ability is strong, the better the performance of cross-border mergers and acquisitions, that related to cross-border mergers \& Acquisitions of transnational mergers and acquisitions, internal control and enterprise performance is positive. This paper presents the internal control mechanism of the integration of cross-border mergers and acquisitions culture, expansion and development of the theory of internal control field, enrich the research related to the transnational merger and acquisition performance, discusses the important status of internal control in enterprises in cross-border mergers and acquisitions, to study the relationship between transnational merger and acquisition activities and internal control system and has a certain practical significance.
\end{abstract}

\section{Introduction}

In recent years, the Chinese government continues to promote the construction and improvement of enterprise internal control, therefore, the internal control has become a hot topic in academic research, the research focus has been placed on the internal control of the economic consequences, but few research on internal control of mergers and Acquisitions' activity in multinational enterprises, the unceasing perfection of internal control can improve transnational merger cultural integration ability, M \& a performance, this paper focuses on. This paper chose the transnational mergers and acquisitions, rather than other economic activities, because of transnational merger and acquisition is one of the major economic activities, and is also an important step for enterprises to expand overseas market, affect greatly economic activity.

\section{Theoretical Analysis and Hypothesis}

\subsection{Internal Control,Cross-border Mergers and Cultural Integration}

The empirical analysis on the domestic and foreign related enterprises transnational mergers and acquisitions, mainly concentrated in the merger performance, usually from theory and case analysis analysis of cross-border mergers and acquisitions corporate culture integration [1], empirical analysis is generally associated with the culture integration in transnational merger and acquisition ability evaluation, pay less attention to cultural integration of transnational merger and acquisition. For example, the Lenovo Inc of IBM cultural integration, cultural integration of the Thomson TCL 
company, including Lenovo, TCL company is a typical representative of eastern culture, IBM and Thomson is a typical representative of western culture, is a typical enterprise cross-border mergers \& acquisitions.

The quality of internal control is an important factor affecting the cultural integration ability of transnational mergers and acquisitions, which runs through the whole process of enterprise mergers and acquisitions, cultural integration[2]. The cultural integration of transnational mergers and acquisitions can be divided into four periods: cultural contact period, cultural collision period, cultural break in period, and cultural construction period. The influence of internal control on the cultural integration ability of transnational mergers and acquisitions can be analyzed from the following four aspects: (1) Cultural contact period. Effective internal control can be in contact with the enterprise transnational merger cultural integration, improve the cultural differences and conflicts to investigate the accuracy of [3], this stage has two main tasks: the enterprise to identify the cultural differences, cultural adaptability evaluation; establish the transnational enterprise merger cultural integration mode. At this stage, enterprises to establish effective internal control system, the formation of mutual decision system, strict control and supervision in the contact period of culture integration in transnational merger and acquisition activities, to ensure that the cultural communication of information, effectively prevent the opportunism of the management. (2) Cultural collision period. During the collision period of the cultural integration of enterprises' transnational mergers and acquisitions, institutional changes, personnel changes, the establishment of new organizational structure and reshuffle of management teams are often existed. Effective internal control can carry out supervision and management of cultural conflict, cultural integration development progress, can optimize the target culture in the process of cultural integration, the strategic goal of management focus on cultural differences and the existence of complementary, to reduce the risk size of cultural collision period, reduce mistakes. (3) Cultural break in period. The more effective the internal control, the higher the quality of enterprise managers. In the enterprise culture in transnational merger integration, the implementation of the new enterprise system, adjust the relevant management, gradual integration of two cultures, in the meantime, managers through training and communication to employees, encourage employees to the new enterprise culture identity. The internal control efficiency to promote the implementation of this process, the frequent communication between internal staff, reduced the original cultural differences, reduce the managers in the disagreement period of cultural integration, mutual coordination between different interests, clear management staff in the cultural integration in their duties, improve cultural integration in the process of implementation efficiency, thus forming a new cohesion. (4) Cultural construction period. As the last period of transnational merger cultural integration, cultural innovation throughout the whole process of cultural integration, effective internal control will strengthen the adaptability of employees to the culture, choose the excellent culture gene, study the external culture, based on the local culture, to create a new corporate culture, internal control and encourage employees to play the potential. To improve the working enthusiasm, continue to create their own value, to adapt to the new cultural environment.

\subsection{Internal Control and Merger Performance}

The domestic and foreign scholars mainly from two aspects of internal control and the performance of mergers and acquisitions, one is starting from the internal control and practice, acquisition of each link of business risk, puts forward the solving measures, establish and perfect the internal control system of the [4]; the two is the empirical analysis on the relationship between 
internal control and acquisition performance, impact on the enterprise merger and acquisition the analysis of internal control.

First, Ashbaugh-Skaife[5] points out that the Sarbanes act has a profound impact on mergers and acquisitions, and that the effectiveness of internal control can improve the value of mergers and acquisitions. Cui Yongmei [6] studies the important role of merger performance, and believes that merger performance is one of the key links in enterprise mergers and acquisitions, and the establishment of a corresponding internal control system to realize the identification and effective control of risks.

Second ideas, Zhao Xi [7] using structural equation model, the executive power, internal control, the relationship between the performance of the three merger analysis, concluded that the internal control can improve the performance of mergers and acquisitions. Yang [8] studies the relationship between the quality of internal control, the performance of M \& A and the bankruptcy risk of the acquirer, which shows that the internal control is positively related to the merger performance and negatively related to the bankruptcy risk of.

Based on this, the hypothesis of this paper is put forward:

Hypothesis 1: the higher the quality of enterprise internal control, the better the ability of cultural integration of transnational mergers and acquisitions.

Hypothesis 2: the higher the quality of internal control, the better performance of mergers and acquisitions after cross-border mergers and acquisitions.

\section{Research Design}

\subsection{Measurement of Variables and Construction of Models}

1.The measurement of cultural integration ability of transnational mergers and acquisitions

Research on the transnational merger performance cultural integration, cultural integration for cross-border mergers and acquisitions success can be used EPS (earnings per share) to measure and reflect the share to create profit after tax, refers to the ratio of net income this year and the total number of shares, shareholders to measure the enterprise's profitability, if the enterprise cross-border mergers and acquisitions after the completion of each year EPS (earnings per share) compared to before the completion of the acquisition of a significant growth or small changes, the culture integration in transnational merger and acquisition ability, if the negative growth state, the transnational enterprise merger cultural integration ability.

2. Measurement of cross-border merger performance

3. This paper uses ROE (ROE) to measure the performance of mergers and acquisitions, ROE as the core of DuPont analysis in index system, comparability, comprehensive analysis ability convenient outstanding, can compare the performance of different companies. Net interest rates for the product number, total assets turnover sales net interest rate, equity multiplier three, reflects the profitability and operation ability of the enterprise size, this index is the existing literature for the main index calculation and measure the performance of mergers and acquisitions.

\section{Model Construction}

In order to test the relationship between internal control and cross-border mergers and acquisitions, cultural integration ability and $\mathrm{M} \&$ a performance, the following model is established:

$$
\begin{aligned}
& \text { EPS }_{\mathrm{t}}-\mathrm{EPS}_{-1}=\beta_{0}+\beta_{1} \mathrm{ICQ}+\beta_{2} \text { ASSETS }+\beta_{3} \mathrm{LEV}+\beta_{4} \mathrm{EXPER}+\beta_{5} \mathrm{AGE}+\beta_{6} \mathrm{GROW}+\beta_{7} \mathrm{CFO}+\beta_{8} \mathrm{SOE}+\xi \\
& \mathrm{ROE}_{\mathrm{t}}-\mathrm{ROE}_{-1}=\beta_{0}+\beta_{1} \mathrm{ICQ}+\beta_{2} \text { ASSETS }+\beta_{3} \mathrm{LEV}+\beta_{4} \text { EXPER }+\beta_{5} \mathrm{AGE}+\beta_{6} \mathrm{GROW}+\beta_{7} \mathrm{CFO}+\beta_{8} \mathrm{SOE}+\xi
\end{aligned}
$$

$\mathrm{EPS}_{\mathrm{t}}-\mathrm{EPS}_{\mathrm{t}-1}$ It means that transnational mergers and acquisitions of enterprises have completed the multinational cultural integration ability in it. $\mathrm{ROE}_{\mathrm{t}}-\mathrm{ROE}_{\mathrm{t}-1}$ Represents transnational mergers 
and acquisitions $(t=1,2,3)$ of enterprises in $t$ years. ICQ is the natural logarithm of control index. Tiandihengyi China listed company, is the main test variable; ASSETS is the size of the company, taking the natural logarithm of total assets; LEV is represented by financial leverage, asset liability ratio; EXPER for cross-border mergers and acquisitions experience in business in the past 3 years to complete the number of times said AGE listed years; Ln, (listed years +1) said. GROW is the ability to grow, to (the year operating income year operating income) / year operating income; CFO for cash flow to net cash flow / total assets; SOE is a dummy variable, said the nature of property rights of state-owned enterprises was 1 , or 0 . The symbols and sizes reflect the direction and extent of the influence of internal control on corporate mergers and acquisitions, cultural integration and $\mathrm{M} \& \mathrm{a}$ performance.

Table 1 variable definition table

\begin{tabular}{|c|c|c|}
\hline Variable name & Variable symbol & Variable description \\
\hline $\begin{array}{l}\text { Transnational mergers and } \\
\text { acquisitions, cultural } \\
\text { integration ability }\end{array}$ & $\mathrm{EPS}_{\mathrm{t}}-\mathrm{EPS}_{\mathrm{t}-1}$ & $\begin{array}{l}\text { Represents the relative situation of multinational } \\
\text { cultural integration in } t, t=1,2,3\end{array}$ \\
\hline $\begin{array}{l}\text { Transnational mergers and } \\
\text { acquisitions performance }\end{array}$ & $\mathrm{ROE}_{\mathrm{t}}-\mathrm{ROE}_{\mathrm{t}-1}$ & $\begin{array}{l}\text { Represents the relative performance of } \\
\text { transnational mergers and acquisitions in } t \text {, } \\
t=1,2,3\end{array}$ \\
\hline Internal control quality & ICQ & $\begin{array}{l}\text { Tiandihengyi. Control index of the natural } \\
\text { logarithm of listed companies }\end{array}$ \\
\hline company size & ASSETS & The natural logarithm of the total assets \\
\hline financial leverage & LEV & Asset liability ratio \\
\hline $\begin{array}{l}\text { Transnational merger and } \\
\text { acquisition experience }\end{array}$ & EXPER & $\begin{array}{l}\text { Over the past } 3 \text { years, the number of } \\
\text { cross-border mergers and acquisitions }\end{array}$ \\
\hline Listed years & AGE & Ln ( Listed years +1 ) \\
\hline Growth ability & GROW & $\begin{array}{l}\text { (Revenue for the year - Last year's operating } \\
\text { income ) /Last year's operating income }\end{array}$ \\
\hline cash flow & $\mathrm{CFO}$ & Net cash flow / total assets \\
\hline Property right nature & SOE & $\begin{array}{l}\text { Dummy variables were } 1 \text { for state-owned } \\
\text { enterprises, or } 0\end{array}$ \\
\hline
\end{tabular}

\subsection{Sample Selection and Data Sources}

This paper based on the 2015-2016 acquisition of listed company has completed mergers and acquisitions, cross-border mergers and acquisitions selected as samples, and in accordance with the following criteria were selected out: (1) From the business characteristics, profit structure and other enterprises are large enterprises, drawing the financial and insurance industry enterprises; (2) Excluding cross-border mergers and acquisitions belongs to related parties transaction samples; (3) Excluding in the year to complete the merger and acquisition within three years, and completed mergers and acquisitions of listed companies; (4) Excluding incomplete data samples. After the above selection procedure, 49 observations were obtained, of which 17 were in 2015 and 32 in 2016. The data in this paper are from the CSMAR database of Tai'an, China. This paper uses Excel software to sort out the data and uses STATA15.0 to analyze and calculate the data. 


\section{Empirical Results and Analysis}

\subsection{Descriptive Analysis}

As shown in Table 2, transnational merger and acquisition that year and earnings per share after 3 years (EPS) compared to the year before completion of transnational mergers and acquisitions in the increasing trend of transnational merger and acquisition completed that year, after the completion of the annual performance was higher than that of the previous year's performance, different sample acquisition performance variables, culture integration in transnational merger and acquisition variables there were significant differences with other variables, the results showed that the sample identification is good, through the correlation analysis showed that the ability of merger and acquisition performance is positively related to ICQ and enterprise M \& a cultural integration (limited space not listed), initially supported the hypothesis 1 and hypothesis 2.

Table 2 Descriptive Statistics

\begin{tabular}{|c|c|c|c|c|c|}
\hline Variable name & mean value & $\begin{array}{c}\text { standard } \\
\text { deviation }\end{array}$ & $\begin{array}{c}\text { minimum } \\
\text { value }\end{array}$ & Median & Median \\
\hline EPS $_{0}$ EPS $_{-1}$ & 0.0787169 & 0.2642385 & -0.382369 & 0.052416 & 1.356238 \\
\hline EPS $_{1}$ EPS $_{-1}$ & 0.0624275 & 0.4452913 & -1.062835 & 0.021354 & 2.456121 \\
\hline EPS $_{2}$-EPS $_{-1}$ & 0.0624647 & 0.4549305 & -0.512094 & -0.001725 & 2.315464 \\
\hline EPS $_{3}$ EPS $_{-1}$ & 0.0635163 & 0.4631257 & -0.625849 & -0.000927 & 2.378952 \\
\hline ROE $_{0}$-ROE & 0.0119467 & 0.0598645 & -0.125768 & -0.001648 & 0.175384 \\
\hline ROE $_{1}$-ROE & 0.1281745 & 0.0768351 & -0.243987 & -0.049583 & 0.135260 \\
\hline ROE $_{2}$-ROE & 0.0925987 & 0.1157321 & -0.708435 & -0.070548 & 0.379582 \\
\hline ROE $_{3}$-ROE & 0.0837285 & 0.1264859 & -0.917548 & -0.123595 & 0.067156 \\
\hline ICQ & 6.571094 & 0.2972561 & 6.051254 & 6.556284 & 6.875261 \\
\hline ASSETS & 21.7539 & 1.172495 & 20.245286 & 22.56325 & 26.57168 \\
\hline LEV & 0.4789736 & 0.253792 & 0.2197251 & 0.513625 & 0.857492 \\
\hline EXPER & 0.1531873 & 0.3731681 & 0 & 0 & 1 \\
\hline AGE & 2.217564 & 0.5674254 & 0.687256 & 2.256172 & 2.873194 \\
\hline GROW & 0.4915672 & 1.9752637 & -0.715248 & 0.167483 & 16.43917 \\
\hline CFO & 0.0605849 & 0.0915263 & -0.156428 & 0.061538 & 0.465721 \\
\hline SOE & 0.6357452 & 1.2142568 & 0 & 1 & 1 \\
\hline
\end{tabular}

\subsection{Multivariate Regression Analysis}

1.Internal control and cross-border mergers and acquisitions, cultural integration capability

Table 3 is the test result of the cultural integration ability of internal control and transnational mergers and acquisitions. Among them, the ICQ coefficient is significantly positive, indicating the higher internal control, transnational enterprises merger cultural integration ability is strong; the enterprise scale (ASSETS) scale and culture integration in transnational merger and acquisition was negatively related to that larger enterprises, transnational merger and acquisition of the enterprise culture integration ability is weak; transnational mergers and acquisitions experience (EXPER) and cash flow (CFO) integration capability is positively related to mergers and acquisitions are the enterprise culture, transnational mergers and acquisitions experience and cash flow, give more resources of transnational merger and acquisition of cultural integration, cultural integration leads to the stronger ability; financial leverage in the acquisition of the year negative correlation from three years after the start of the first year, the ability to integrate multinational culture strong financial leverage plays a crucial role. Thus, hypothesis 1 is verified. 
Table 3 cultural integration of internal control and transnational mergers

\begin{tabular}{|c|c|c|c|c|c|c|c|c|}
\hline \multirow[b]{2}{*}{ variable } & \multicolumn{2}{|c|}{$\mathrm{EPS}_{0}-\mathrm{EPS}_{-1}$} & \multicolumn{2}{|c|}{$\mathrm{EPS}_{1}-\mathrm{EPS}_{-1}$} & \multicolumn{2}{|c|}{$\mathrm{EPS}_{2}-\mathrm{EPS}_{-1}$} & \multicolumn{2}{|c|}{$\mathrm{EPS}_{3}-\mathrm{EPS}_{-1}$} \\
\hline & coefficient & $\begin{array}{l}\text { The value of } \\
\mathrm{T}\end{array}$ & $\begin{array}{l}\begin{array}{l}\text { coeffi } \\
\text { cient }\end{array} \\
\end{array}$ & $\begin{array}{l}\text { The value of } \\
\mathrm{T}\end{array}$ & coefficient & The value of $\mathrm{T}$ & \begin{tabular}{l|l}
$\begin{array}{l}\text { coeffi } \\
\text { cient }\end{array}$ \\
\end{tabular} & The value of $\mathrm{T}$ \\
\hline ICQ & $0.843^{*}$ & 2.13 & $0.718^{*}$ & 2.15 & $1.594^{*}$ & 2.45 & $1.715^{*}$ & 2.67 \\
\hline ASSETS & -0.0119 & -0.38 & $\begin{array}{c}-0.031 \\
2\end{array}$ & -0.74 & -0.0234 & -0.32 & $\begin{array}{c}-0.031 \\
5\end{array}$ & -0.41 \\
\hline LEV & -0.006 & -0.05 & 0.318 & 0.21 & -0.169 & -0.63 & 0.123 & 0.19 \\
\hline EXPER & 0.0597 & 0.65 & 0.173 & 1.76 & 0.294 & 1.54 & 0.315 & 1.61 \\
\hline AGE & -0.012 & -0.35 & -0.012 & 0.06 & 0.003 & -0.61 & 0.004 & -0.54 \\
\hline GROW & 0.009 & 0.11 & 0.001 & 0.12 & 0.001 & -0.4 & 0.001 & 0.13 \\
\hline $\mathrm{CFO}$ & $0.673^{*}$ & 2.35 & $0.716^{* *}$ & 3.35 & $1.121^{* * *}$ & 3.26 & $1.312^{* * *}$ & 3.48 \\
\hline SOE & -0.031 & 0.31 & 0.016 & 0.87 & 0.041 & 0.69 & 0.063 & 0.92 \\
\hline Adjusted $\mathrm{R}^{2}$ & \multicolumn{2}{|c|}{0.1262} & \multicolumn{2}{|r|}{0.0913} & \multicolumn{2}{|c|}{0.1618} & \multicolumn{2}{|r|}{0.2135} \\
\hline $\mathrm{F}$ & \multicolumn{2}{|c|}{1.95} & \multicolumn{2}{|r|}{1.75} & \multicolumn{2}{|c|}{$2.43^{*}$} & \multicolumn{2}{|r|}{$3.26^{*}$} \\
\hline
\end{tabular}

Note: $*, * * * * *$ means significant at $5 \%, 1 \%$ and $0.1 \%$ levels respectively

\section{Internal Control and merger performance}

Table 4 shows the results of internal control and cross-border merger performance. Among them, the ICQ coefficient is positive, which means that the higher the internal control, the stronger the performance of transnational mergers and acquisitions. The enterprise scale (ASSETS) was negatively related to the performance of cross-border mergers and acquisitions and enterprise scale, enterprise scale is larger, enterprise transnational merger and acquisition performance of the weak; cross-border mergers and acquisitions (EXPER) experience more rich, more high performance acquisition; enterprise growth ability (GROW) and (AGE) and the listed years of transnational merger and acquisition was negatively related to that enterprises listed years longer, grow stronger, enterprises often do not care about the cross-border mergers and acquisitions, only focus on their own development, leading to weaker cross-border mergers and acquisitions. The more cash flow (CFO), enterprises have more capital to complete cross-border mergers and acquisitions, mergers and acquisitions more powerful. Thus, hypothesis 2 is verified.

Table 4 internal control and cross-border merger performance

\begin{tabular}{|c|c|c|c|c|c|c|c|c|}
\hline \multirow[b]{2}{*}{ variable } & \multicolumn{2}{|l|}{$\mathrm{ROE}_{0}-\mathrm{ROE}_{-1}$} & \multicolumn{2}{|c|}{$\mathrm{ROE}_{1}-\mathrm{ROE}_{-1}$} & \multicolumn{2}{|c|}{$\mathrm{ROE}_{2}-\mathrm{ROE}_{-1}$} & \multicolumn{2}{|c|}{$\mathrm{ROE}_{3}-\mathrm{ROE}_{-1}$} \\
\hline & coefficient & $\begin{array}{l}\text { The value } \\
\text { of } \mathrm{T}\end{array}$ & coefficient & $\begin{array}{l}\text { The value } \\
\text { of } T\end{array}$ & coefficient & $\begin{array}{l}\text { The value } \\
\text { of } T\end{array}$ & coefficient & $\begin{array}{l}\text { The value } \\
\text { of } \mathrm{T}\end{array}$ \\
\hline ICQ & $0.173^{*}$ & 2.17 & 0.168 & 1.83 & $0.319^{*}$ & 2.39 & 0.231 & 2.16 \\
\hline ASSETS & -0.1315 & -1.27 & -0.0145 & -1.24 & -0.216 & -1.23 & -0.315 & -1.32 \\
\hline LEV & $0.0901^{*}$ & 2.12 & 0.0912 & 1.97 & -0.193 & -2.61 & -0.2103 & -2.53 \\
\hline EXPER & 0.0015 & 0.05 & 0.0042 & 0.13 & 0.0191 & 2.17 & 0.0201 & 2.19 \\
\hline AGE & -0.025 & -0.68 & -0.035 & -0.04 & -0.019 & -0.02 & -0.024 & -0.03 \\
\hline GROW & $-0.123^{* * *}$ & -3.81 & $-0.093^{* * *}$ & -5.96 & $-0.124^{* * *}$ & $-0.124^{* * *}$ & $-0.135^{* * *}$ & -0.13 \\
\hline CFO & $0.362^{*}$ & 1.76 & $0.269^{*}$ & 1.64 & 0.153 & 0.912 & 0.173 & 0.816 \\
\hline SOE & 0.036 & 0.84 & 0.051 & -0.17 & -0.011 & -0.78 & 0.076 & -0.57 \\
\hline Adjusted $\mathrm{R}^{2}$ & \multicolumn{2}{|c|}{0.0981} & \multicolumn{2}{|c|}{0.0871} & \multicolumn{2}{|c|}{0.2542} & \multicolumn{2}{|c|}{0.3145} \\
\hline $\mathrm{F}$ & \multicolumn{2}{|c|}{1.83} & \multicolumn{2}{|c|}{1.63} & \multicolumn{2}{|c|}{$3.63^{* *}$} & \multicolumn{2}{|c|}{$4.13^{* *}$} \\
\hline
\end{tabular}

Note: $* * *, * * *$ means significant at $5 \%, 1 \%$ and $0.1 \%$ levels respectively 


\subsection{Robustness Test}

For the robustness test on the above results, usedEPS $\mathrm{Exaxt}_{\mathrm{EPS}}-\mathrm{ES}_{\max -1}$ to measure enterprise transnational merger cultural integration, test in ICQ is significantly positive, indicating the higher the quality of internal control, enterprise transnational merger cultural integration ability is strong, consistent with the hypothesis of 1 results respectively; with total asset turnover and sales net interest rate, equity multiplier measure of multinational enterprises $\mathrm{M}$ \& a performance robustness test, ICQ is significantly positive, the results of this study did not show significant changes, with the assumption that 2 results are consistent.

\section{Conclusion}

This paper takes transnational mergers and acquisitions of CSMAR listed companies in Tai'an as the sample, and examines the impact of internal control on corporate cross-border mergers and acquisitions, cultural integration ability and merger performance. In the study of cross-border mergers and acquisitions, the lack of attention to the ability of cultural integration of cross-border mergers and acquisitions, few documents through empirical analysis to test the role and consequences of internal control on business activities. In this paper, after the completion of EPS through cross-border mergers and acquisitions (earnings per share) the amount of change as an alternative variable, cross-border mergers \& acquisitions ability research shows that the quality of internal control and culture integration in transnational merger and acquisition ability, mergers and acquisitions performance are positively related. The policy implications of this study are: one is the enterprise should not only meet the supervision requirements, but also to help the construction of internal control system, revenue benefits to the enterprise internal control becomes the enterprise to create value of the catalyst; the two is the need to implement the internal control in the actual business activities, play a strategic role in internal control, monitoring and guidance strengthening the role of internal control in the management, enhance the culture integration in transnational merger and acquisition ability, improve the performance of cross-border mergers and acquisitions. This research focus is on mergers and acquisitions and mergers and acquisitions performance transnational cultural integration ability, focus will be the future research is the internal control as well as the choice of transnational merger cultural integration mode of the number of mergers and acquisitions of transnational mergers and acquisitions, target selection.

\section{References}

[1] Goh, B.W., and D.Li. 2011. Internal controls and conditional conservatism[J]. The Accounting Review, 86(3):975-1005.

[2] Doyle, J., W. Ge, and S. McVay. 2007. Accruals quality and internal control over financial reporting [J] .The Accounting Review, 82(5):1141-1170.

[3] $\mathrm{Lu} \mathrm{X}$. Research on the impact of internal control on mergers and acquisitions performance of listed companies [D]. Tianjin University, 2011.

[4] Lin Zhong Gao, Xu Hong, Rui Chen. External earnings pressure, internal control and mergers and acquisitions of listed companies. [J]. audit and economic research, 2016 (03): 21-30.

[5] Ashbaugh-Skaife, H., D. Veenma and D.Wangerin.2013.Internal control over financial reporting and managerial rent extraction: Evidence from the profitability of insider trading [J] .Journal of Accounting and Economics, 55(1):91-110. 
[6] Cui Yongmei, Yu Xuan. Research on internal control evaluation of strategic mergers and acquisitions based on process [J]. accounting research, 2011 (06): 57-62.

[7] Zhao Xi, Zhang Xishuan. Internal control, executive power and performance: evidence from China [J]. Nankai Business Review of the securities market, 2013 (02): 75-81.

[8] Yang Daoguang, Zhang Chuancai, Chen Hanwen. Internal control, M \& A integration ability and $\mathrm{M} \&$ A results. Empirical evidence from Listed Companies in China [J]. audit research, 2014 (03): 43-50. 